\title{
ATLANTIS IN SPAIN
}

\section{Papamarinopoulos S.P.}

University of Patras, Department of Geology, Patra, Greece

\section{Part III: Removing the misunderstandings}

\begin{abstract}
Plato three times in his text mentioned that the Atlantean events occurred 9000 years before Solon's ${ }^{6} \mathrm{~h}$ century B.C. but once he also mentioned 8000 years for the same events. Taking into account the number of the Athenian Kings and the mean span of their successive generations which is more or less 30 years who governed Athens before the $1^{2 t} h$ century B.C., it is concluded that all of them together span a 350 year period which of course has nothing to do with the $1^{0 t} h$ millennium claimed by Plato. These Kings together with Theseus the first King of Athens correspond in the 2ed millennium B.C. The archaeological findings in the Acropolis mentioned by Plato, the collapse of the Achaean World, the loss of the writing system in Greece, the assault of the Atlantes have been proved to be of the $1^{2 t} h$ century B.C. The ancient sources and the archaeological findings in Egypt show a lunar calendrical system practised by the priests who transmitted the story of Atlantis to Solon in the ${ }^{6 t}$ h century B.C. Dividing therefore these thousands of years by 12.37 which is the number of the full moon in a year the platonic dates are landing in the end of the $1^{3 t} h$ to the beginning of the $1^{2 t} h$ century B.C.Considering the visibility from Atlantis of the celestial bears which are implied as general North indicators Plato himself invalidated the $1^{\text {ot }} \mathrm{h}$ millennium B.C., as the period of the Atlantean events, since no celestial bears can play such a role as celestial North's constellation because the Earth's axis of rotation does not pass through them. This conclusion forces a different interpretation in Plato's thousands of years for the Atlantean events. The only logical explanation is that the thousands of years is moon months understood as years. Plato used the word island for Atlantis which is associated with events belonging in the late Bronze Age in which the word island had the meaning of either promontory or peninsula. The resolution of this major issue removed entirely the 2400 year misunderstanding between the word island and peninsula since Herodotus in the ${ }^{5 t} \mathrm{~h}$ century B.C. added the word peninsula for first time offering to the island today's exclusive meaning. In other words Atlantis was as much an island as Peloponnesus was which an island was never. He also used with the common word Atlantis three different geological entities: a giant island, a horseshow basin and a system of concentric rings associated with geothermal springs and with black, white and red rocks.
\end{abstract}

\section{Intoduction}

The story was transmitted to Solon in the 6th century B.C. from the Egyptian priesthood in Sais. The latter is shown in the following Figure 1. At Sais Solon was told that the Atlantean events were realized thousands of years before his period. It is important to analyze this incredible time statement versus our modern scientific knowledge. 


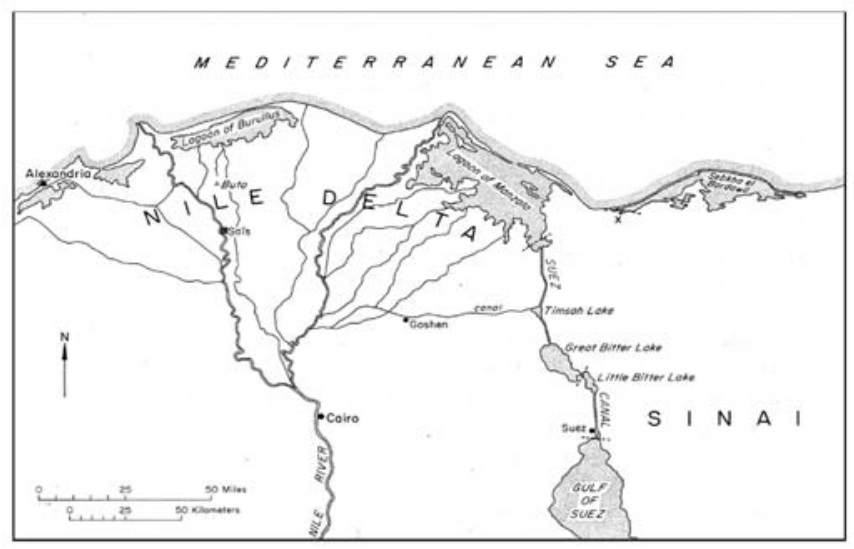

Fig. 1: Sais' location in the Nile's delta is shown.

\section{Normalization of the time of the Atlantean and Athenian events}

Plato is describing the war of the Atlantes against all nations and then mentions the thousands of years as the years of the Atlantean's events realization. He does it in Criti 109.c.3-109.c.6 as follows:

"Now first of all we must recall the fact that 9000 is the sum of years since the war occurred, as it is recorded, between the dwellers beyond the pillars of Heracles and all that dwelt within them".

In fact he says 9000 years three times in his text and 8000 year one time. He, therefore, gives the impression to the reader of his dialogues of an enormous time span of the Atlantean events. We need to analyze this information properly in order to see if it is correct. Firstly we need to examine the Athenian Kings list which Plato presents since these people, before Theseus' time, were supposed to Atlantis' opponents (Mitropetrou, 2010).

The names were the following Cecrops, Erechtheus, Erichthonius, Erysichthon, and others before Theseus, (Plato, Critias, 10 a 7-8). But these names do not refer to the tenth millennium, but to the second millennium B.C. Combining the traveler Pausanias (Graeciae Descriptio, 1, 2, 6) and Apollodorus (Bibliotheca, 3, 190), we learn all the kings of Attica before Theseus:

Actaeus, first king of Attica, Cecrops, Erysichthon, Cranaus, Erichthonius, son of Hephaestus and Earth, Pandion, Erechtheus, Cecrops II, Pandion II, Aegeus, Theseus

Therefore, the ten kings of Attica before Theseus cover a time period of 350 years roughly. However, no matter what era, of course before the Trojan War, might Theseus, the patron hero of Athens, be placed in, Actaeus does not exceed chronologically the year 1600 B.C. The most possible chronological period of his reign is the $16^{\text {th }}$ century B.C. (Mitropetrou, 2010). Consequently Plato himself defines the Bronze Age period as the time of the Athenian Kings who faced the Atlanteans. Does he contradict himself with 9000 years he says in his text? The Egyptian priesthood by tradition, and in contract with the civilian pharaonic nomenclature, did not use solar years, but lunar years making practice of two different lunar calendars as Egyptology teaches and as Manetho, the Greek spoken Egyptian

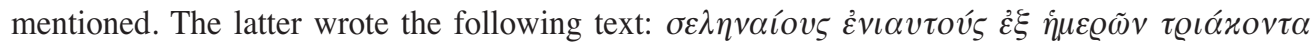

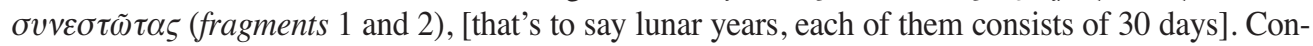
sequently the 9,000 lunar years are equal to 9,000 months as Diodorus suggested, (The Library of History, 1,26,2,1-4,3). Based mainly on Manetho and Diodorus and as Egyptology teaches as well -in ancient Egypt, the priests used two different lunar calendars but the pharaonic officials used solar cal- 


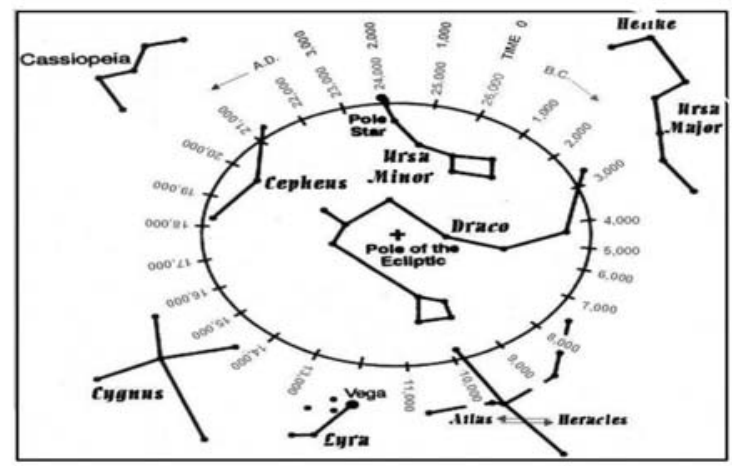

Fig. 2: A unique tran-stellar compass and clock taken from the Hellenic mythology defines constellations which play the role of exact and general celestial North versus time in a 26,000 years time span. It works when the Earth's axis of rotation, in its mode of extension through space, intersects a particular star of one of the constellation shown above. Due to the combined attraction of the moon and the sun on the planet the Earth's axis of rotation scans the celestial sphere in a 26,000 time span. Consequently the 9000 and/or 8000 assumed solar years of the Egyptian priests, mentioned to Solon, as the period of the Atlantean' events realization could not be correct because the celestial bears could not possibly be visible from an observer on Atlantis within the $10^{\text {th }}$ millennium B.C. This unexpected result was taken from Plato's text. It forces us to accept that 9000 solar years were actually months considered as moon years by the Egyptian priests. Dividing these two numbers with the 12.37 , which is the number of the full moons in a year, we land within the end of the $13^{\text {th }}$ and the beginning of the $12^{\text {th }}$ century B.C. In that period the celestial bears could be used as general celestial North indicators.

endars. Therefore, the possible times of the war against the Atlanteans (Sea Peoples) are within the first quarter of $13^{\text {th }}$ (exactly, 1288 B.C., that is 727.56 plus 561, the year of the Solon's visit in Egypt) and the last quarter of $13^{\text {th }}$ century B.C. (exactly, 1207B.C., that is 646.72 plus 561, the year of the Solon's visit in Egypt), if the time spans are divided by the number 12.37, which is the number of full moons in a year. These time spans (727.56 and 646.72 solar years respectively) are modifications of the Platonic 9,000 and 8,000 years mentioned in Timaeus and Critias, (Mitropetrou, 2010). If we examine the rest of the information described by Plato analytically we recognise again that the time of all the events he describes in prehistoric Athens and in Greece in general are all proved to be archaeologically within the early $12^{\text {th }}$ century B.C., (Papamarinopoulos, 2010).

But Plato even gives additional information about Atlantis' orientation which by itself offers highly interesting time constraints to the text's analyst. Plato is saying the following:

Criti 118b.1-118b.2

"and this region, all along the island, faced towards the south and was sheltered from the northern blasts"

This description offers Atlantis'orientation and further implies the time in which this observation was done because it involves the celestial bears. The latter offers a general indication of the celestial North. We already know that Plato's information in Timaeos and Critias originates in late $12^{\text {th }}$ century B.C. and thus has some Achaean component too in addition to the initial Egyptian one. The celestial bears reminds us Homer indicating North who indeed describes North with the bears.

If the Platonic information was much older in the range of thousands of years, as he mentions in his text, then the celestial bears would not be used. Other constellations offering general or exact North had to be used. For instance the Dragon constellation offers a star as an exact North. It was known to many cultures round about $2.700 \mathrm{yr}$ B.C. The initial transmitter in Plato's text does not use it. The reader can see in Figure 2 periods in the past in which exact North was available. In a circle of 


\section{The island in Egyptian hieroglyphics}
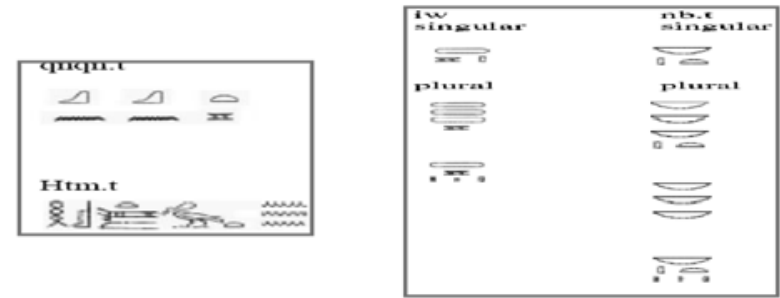

Fig. 3: The Egyptian words meaning coast available in the Egyptian writing system up to the $6^{\text {th }}$ century B.C. are the closer to the case of the island.

roughly 26.000 years various constellations offered a star through which the axis of the earth's extension once passed. Consequently, the bears point Atlantis' Bronze Age observation much earlier than Dragon's time and certainly much earlier than Heracles' time, which is in $10.000 \mathrm{yr}$ B.C., presented a star to play the role of an exact North.

It is a further proof, which will be added in those which will be presented in another part of the text, that the text mentioned time spans in moon years and therefore the time of the events is not 9.600 yr B.C. in solar years. Otherwise North would be a star in Heracles constellation and not the constellation of the bears. But there is a further implication and this is that the celestial bears can not be seen 25 degrees south of the equator. In other words the southern hemisphere, below 25 degrees, can not be the place where the land of Atlantis was located.

\section{Island's evolving meaning versus time}

Solon wrote in his notes the case of a giant island which was missed in a single night of misfortune. The case was written down by Plato, since he was Solon's ancestor. The lost island, presented as a paradise, became a source of a large amount of published books with many speculative theories.

Before we examine parts of Plato's text and analyze it we shall attempt to understand the meaning of the word's island from the stand point of the Egyptian and then of the Greek language.

All Egyptologists agree that none of the available words in Egyptian scripts up to the $6^{\text {th }}$ century B.C., shown in Fig.3, in which Solon visited Egypt had the meaning which the word had in Plato's time in the $4^{\text {th }}$ century B.C. In the following Fig. 2 the words which the Egyptians used to describe a coast are shown since no other word existed in describing something closer to the 6th century's B.C. Greek meaning of an island.

In the case of the Greek language it is known that the word island got the meaning we have today only in the $5^{\text {th }}$ century B.C. when Herodotus added for first time the word peninsula. Because Atlantis was an old story in accordance with the platonic text then the word island in Greek, before the $5^{\text {th }}$ century B.C., had the possible meanings of promontory or peninsula. Peloponnese is a good example for demonstrating the above mentioned argument because it was never an island but yet it was called as such always from prehistoric to historic times.

Plato describing Atlantis' size says: Tim24.e.6-24.e.7: "the island which was larger than Libya and Asia together" 


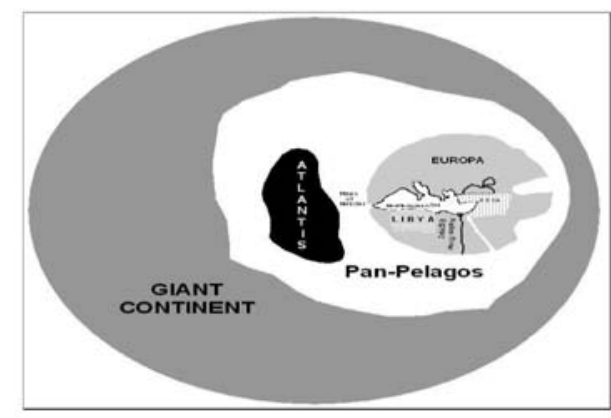

Fig. 4: Plato's world map is shown with the giant island of Atlantis in the middle of the Atlantic Ocean in the experts' eyes who concluded what Plato meant.

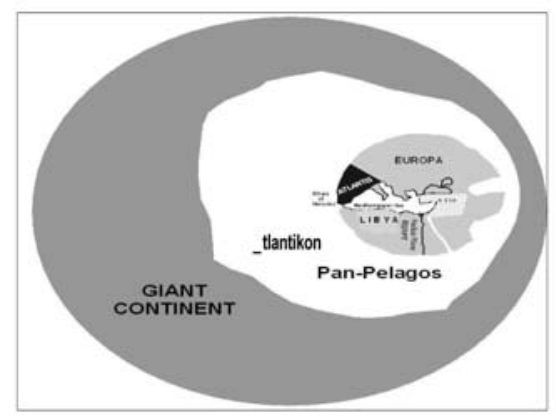

Fig. 5: The map presents Atlantis' island with its Bronze Age meaning, in its correct position, in accordance with the platonic text. Atlantis was as much an island as Peloponnesus and Pharos Island in Alexandreia were in prehistoric times. Both they were peninsulae.

We need to define the concepts of Libya and Asia for the Greeks assuming that some parts of the story of Atlantis may come from Greek sources too. In Fig.3 we show the reader Plato's world map. In that Herodotus' map is emplaced. Asia, for the Greeks of $6^{\text {th }}$ and $5^{\text {th }}$ centuries B.C., was only Anatolia and Middle East and not the present day continent of Asia. East of Asia were other countries like Medeia, Persia and India and others. Libya, for the same centuries, was possibly either all today's North Africa minus Egypt or even a smaller part of North Africa. It is unclear from Herodotus' trip who crossed Libya in ten days what Libya's territory was. The term Ri-Bi or Li-Bi was used for first time in Egyptian in the $12^{\text {th }}$ century B.C. In Fig. 4 we demonstrate to the reader how Atlantis' island was traditionally conceived both by experts and by romantic explorers. Libya and Asia are now shown shaded in their correct positions.

That map shown above was a bitter result produced by those who did not take into account the word's island evolution in the Greek language versus time from the prehistory to the classical period of Greece. They same people did not take into consideration that even in the Egyptian language up to the $6^{\text {th }}$ century B.C. such a meaning did not exist. If Solon's informants were Egyptians they would have had little interest in comparing areas of countries. However, they would have been interested in comparing war capacities of the invading Atlantes with those from their traditional enemies the Libyans and Asians who lived in Libya and Asia as Fig.3 shows. In Fig.5 we demonstrate to the reader where Atlantis Island was. Plato describes very clearly Atlantis' position by saying the following statement.

Tim 24.e.5-24.e.6

\section{"island in front of the mouth which you call Heracles' Pillars"}

Justifiably Plato calls the sea in front of Atlantis Atlanticon pan-pelagos whereas Herodotus calls it Atlantis Sea. Homer, Herodotus and Plato correctly avoided calling that sea Atlantic Ocean because Ocean was a river and a current. Much later received today's meaning. The word island has been preserved in Linear B because the root of the word islander's in genitive has been survived in that ideographic Greek writing system as well. This means that Atlantis was as much as an island as Pharos Island was. Pharos Island was mentioned in Homeric times and in Hellenistic times as well. Chalari et al (2010) with geophysical methods has demonstrated clearly that in the $12^{\text {th }}$ century B.C. Pharos was a peninsula. However, it was called Pharos Island too when the peninsula had been lost even in Alexander's time in the 3ed century B.C. But the reader may say how we know that this pair of Her- 


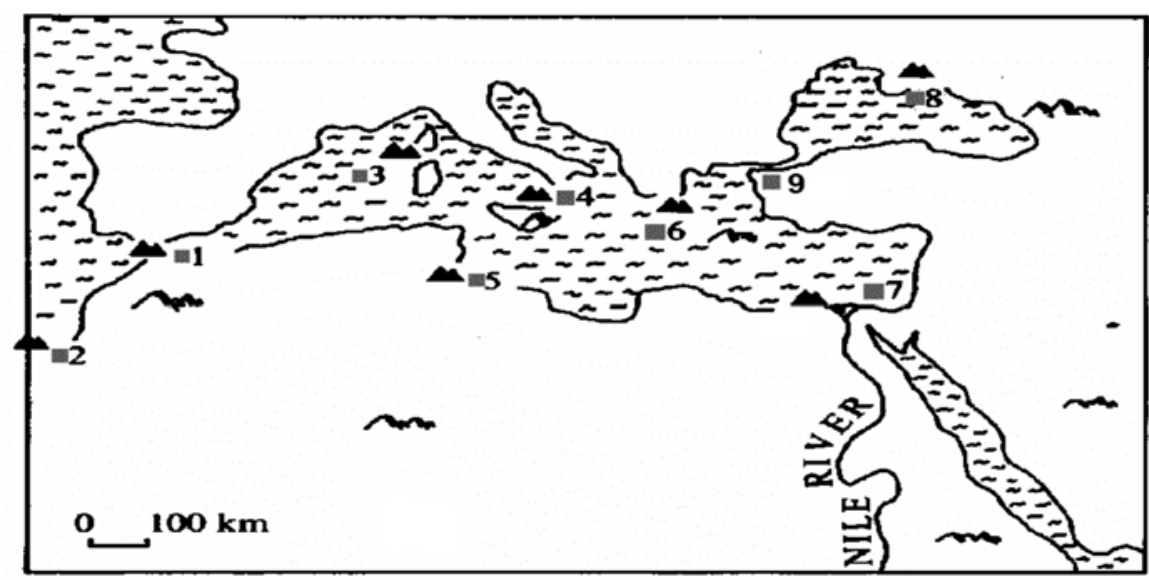

Fig. 6: The distribution of all pairs of Heracles' Pillars (after Zhirov, 1964)

acles' Pillars is definitely the Gibraltar Straits? Did Solon know that these exact pairs were at Gibraltar? The answer is negative. There is not any way of proving historically that he knew but Hesiod who lived earlier, than Solon, in the $7^{\text {th }}$ century B.C. knew. His following passage is very clear proof that the Greeks even before Solon knew where Heracles' Pillars were in connection with Gadeira:

Fragmenta 372.10-372.11 In that Hesiod describes a sea route from Gadeira to Taras city in Italy and the Ionian Islands.

The word ( $\Gamma \alpha \delta \varepsilon\llcorner\varrho o ́ \theta \varepsilon v)$ means from Gadeira demonstrates the case. At first Gadeira is mentioned and then a sea route is mentioned too which connects it with Taras in Italy and the Ionian Sea in Greece respectively. The direction of the sea route is obvious and there is not any confusion whatsoever with other city of Gadeira of the East Mediterranean because Plato called it Gadeiriki meaning, like Chalkidiki, peninsula which does exist only in West Mediterranean. This is an answer to those who attempted to demonstrate that Solon of the $6^{\text {th }}$ century B.C. did not know which pair, from the available nine of Heracles' Pillars, was the one associated with Atlantis' position. According to them, the search for Atlantis had to be sought within the Mediterranean Sea. But on the contrary, the search must be directed within the Atlantic Ocean. Figure 6 shows the distribution of all pairs of Heracles' Pillars. The pair with number 1 is the one Plato meant. Hesiod was the first who gave the answer that the Greeks from the $7^{\text {th }}$ century B.C. knew Cadiz West of Gibraltar. There are, however, also publications corroborating the fact that some contact between Achaean Greeks and Iberians existed even before the $7^{\text {th }}$ century B.C. Martin de La Cruz (1990), studied Mycenaean pottery, dated earlier than the $12^{\text {th }}$ century B.C. found in archaeological excavations in the effluence of Guadalquivir River. This slim, so far, archaeological evidence illustrates that some sort of trade existed between the Achaean Greeks and the Atlantic Ocean Tartessians even before the coming of the Phoenicians.

\section{The common name Atlantis}

Plato made great use of, the invented by him, word Atlantis, for all the three different geological entities shown in Fig.7 producing confusion to careless analysts of his text. This common use of Atlantis' word produced an unwanted confusion because the reader of the platonic text had the impression that Plato meant three different geological entities. The reader also had the impression that a giant island 


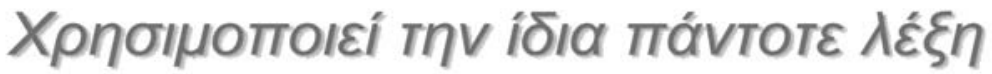

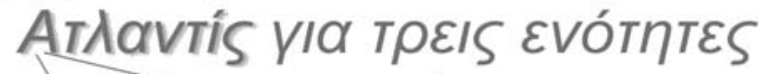

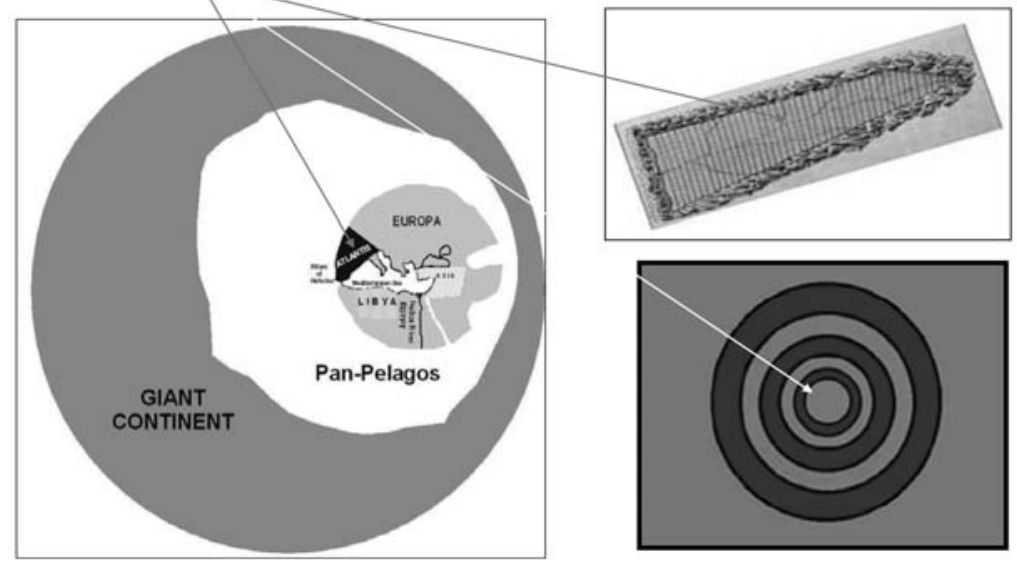

Fig. 7: Plato used the same word Atlantis, invented by him, for three different geological entities shown above. One of them, the concentric scheme of rings, understood as Atlantis, with the geothermal springs and the black, white and red rocks was lost after earthquakes, floods and a land slide was lost. Matton et al.,(2005) offered a geological analysis of such a concentric system which turned to be a diapeirogenic crater. There are of course other types of diapeirogenic craters than that of Richat's case. (platonic basin as Atlantis was constructed by Zhirov following strictly Plato's text, 1970).

of continental size was lost within one day's and night's duration! Figure 7 serves the purpose of clarifying the complex issue of what exactly the reader expects to understand as the lost Atlantis and not. Atlantis' catastrophe is explained by Papamarinopoulos, (2010 Part VI).

\section{Conclusions}

The international experts who rejected entirely Atlantis missed the case because they did not consider the evidence presented by Plato himself about the Athenian Kings' and their number and their mean span of their kingship of ancient prehistoric Athens in connection with the time variant $(9000$ solar years) of his story. They all converged within the 2ed millennium B.C. The evidence of their total span was only 350 years, after Theseus, since the length of each generation is 30 years or so. Their names and their complete sequence originate from the combination of Plato's and other ancient authors' texts. Besides the international experts did not consider the results of the archaeological excavations on the Acropolis of Athens and the mainland of Greece in general and especially of the seismic catastrophes which all converge again within the $12^{\text {th }}$ century B.C. as related to Plato's text!. They also ignored ancient Greek sources and archaeological results in Egypt which all demonstrate in the recognition that the Egyptian priesthood used moon calendars. The same experts did not take into account the meaning's evolution of the word island in Egyptian and in Greek. Finally they did not realised that Plato used the same word Atlantis, invented by him, in order to describe the giant island, a horseshoe shape basin and a concentric ring system with geothermal springs and multicolour rocks. If they had done they would have assisted the resolution of the complexity of Atlantis much earlier than in the end of the last decade of the 21 st century. 


\section{References}

Chalari, A., St. P. Papamarinopoulos, G. Papatheodorou and G.Ferentinos., 2010. The Achaeans' coming to Africa and the island of Pharos. Proceedings of the International Conference: The Atlantis Hypothesis: searching for a lost land, Athens 10-11 November 2008, Publisher: Heliotopos, Editor : Stavros Papamarinopoulos, (in print).

Hesiod.

Homer.

Matton, G., Jebrak M., Lee J. K. M., 2005. Resolving the Richat enigma: Doming and hydrothermal karstification above an alkaline complex. Geology, v.35, no 8, p.p. 665-668.

Martin de la Cruz, J.C., 1990. Die erste mykenische Keramik von der Iberischen Halbinsel. PZ 65/1:49-52.

Mitropetrou, H., 2010. The Four Main Questions of the Platonic Logical Myth of Atlantis. Proceedings of the International Conference: The Atlantis Hypothesis: searching for a lost land, Athens 10-11 November, Publisher: Heliotopos, Editor: Stavros Papamarinopoulos, (In print).

Papamarinopoulos, St.P., 2010b. Atlantis in Spain. Part:II The case of prehistoric Athens. Proceedings of the current volume of the $12^{\text {th }}$ International Symposium of the Hellenic Geological Society, May 19-22.

Papamarinopoulos, St. P., 2007c. A Bronze Age catastrophe in the Atlantic Ocean? Proceedings of the International Conference: The Atlantis Hypothesis: searching for a lost land, Melos Island 11-13 July 2005, Publisher: Heliotopos, Editor: Stavros Papamarinopoulos, p.p., 555-571.

Plato.

Zhirov, N., 1970. Atlantis. Atlantology: Basic problems. Progress publishers, Moscow, p.p. 437. 